Ethiopian Journal of Environmental Studies \& Management 8(1): 45 - 56, 2015.

ISSN:1998-0507

doi: http://dx.doi.org/10.4314/ejesm.v8i1.5

Submitted: October 21, 2014

Accepted: January 12, 2015

\title{
ASSESSING ANTHROPOGENIC IMPACTS USING BENTHIC MACROINVERTEBRATE AS BIO-INDICATORS IN CENTRAL HIGHLAND STREAMS OF ETHIOPIA
}

\author{
ASCHALEW LAKEW \\ Ethiopian Institute of Agricultural Research (EIAR) National Fishery and Aquatic Life \\ Research Centre, P.O.Box, 64, Sebeta, Ethiopia. Email: aschalewlh@yahoo.com
}

\begin{abstract}
Biological indicators particularly those using macroinvertebrate communities are increasingly used to assess the effects of human driven stressors on stream water and habitat quality. The goal of this study was to establish relationships between benthic macroinvertebrate and common stressor types (siltation, agriculture and paper mill waste) in central highlands of Ethiopia. For analysis environmental variables and benthic invertebrate taxa were collected from four streams from November, 2011 to June, 2012. There was a significant difference in conductivity, dissolved oxygen, total phosphorus and five days biological oxygen demand between paper mill waste and other stressor types. In siltation sites, most environmental parameters were not significantly different $(p>0.05)$ from reference and agricultural sites. Sensitive taxa such as Perlidae, Lepidostomatidae, Scirtidae and Philopotamidae were represented in the reference site. Paper mill waste was the worst stressor for deterioration of water quality and cause significant reduction of benthic invertebrate diversity directly by intoxication and indirectly by changing water quality parameters. Agriculture and siltation stressed sites showed major difference in abundance than richness of benthic invertebrates. of 39 benthic macroinvertebrate metrics tested, five metrics representing richness, composition and sensitivity were identified as useful to discriminate stressor groups. These metrics are taxa richness, EPT (Ephemeroptera, Plecoptera and Tricoptera), \% Oligochaeta \& Chironomidae, \% EPT-BCH (EPT without Baetidae, Caenidae and Hydropschidae and ASPT (Average Score Per Taxa). Among others \% EPT-BCH was found effective to separate the effect of siltation from agriculture and reference sites. This study showed that benthic macroinvertebrate metrics were useful to assess the impact of different stressors in Ethiopian central highland stream and rivers.
\end{abstract}

Key Words: Benthic macroinvertebrate, Stressors, Pollution, Metrics, Highland streams

\section{Introduction}

Biological indicators are increasingly used to assess the effects of anthropogenic activities on water and habitat quality of streams. Among biological communities, benthic macroinvertebrates (BMI) are often the taxa group of choice for biomonitoring in streams and rivers (Hellawell, 1986; Rosenberg and Resh, 1993). They are ubiquitous and abundant even in small streams that make biomonitoring to be carried out in almost any type of streams 
and rivers. They are good indicators of several anthropogenic pressures such as water pollution (Armitage et al., 1983) and geomorphological alterations (Negishi et al., 2002). They consist of several species that originate from different systematic categories with different environmental needs - thus they are differentially sensitive to pollutants of various types. Furthermore, standardized sampling and processing methods are well-developed and taxonomic keys and experts are available to identify most benthic macroinvertebrates.

In this study, streams exposed to agricultural activities, reservoir flushing and paper mill waste are generally compared to samples from stream flowing through natural forest with similar underlying habitat and ecoregion. Agriculture is one of the major human activities responsible for nonpoint-source of pollution in streams of Ethiopia. Agricultural practices such as crop cultivation adjacent to streams can lead to soil erosion and subsequent runoff of fine sediments, nutrients and pesticides (Lowrance et al., 1984; Cooper et al., 1986). Similarly stream banks with narrow areas along the stream channel are commonly inspected by cattle for year round availability of green grass. Several studies have shown that high abundance of tolerant benthic macroinvertebrate and low low diversity of sensitive taxa in agricultural impacted streams (Hall et al., 2001; Walsh et al., 2001). However, not all studies have shown such clear trends (Giller and Twomey, 1993; Reed et al., 1994).

Paper mill waste is among many point source pollutant which alters stream water quality and benthic community assemblage. Paper mill effluents contain diverse types of compounds such as fibre and suspended solids, colour, organic matter and nutrient as pollutant factors with adverse environmental impacts (Owens, 1991). Moreover, some of which have deleterious sub lethal or lethal effects (McLeay, 1987). Both contaminants and nutrient enriched effluent disposed into streams alter benthic macroinvertebrate structure directly by intoxication and indirectly by changing water quality parameters in favour of tolerant taxa.

Effect of fine sediment accumulation on benthic macroinvertebrate diversity and composition was not known in Ethiopia. Various studies showed that fine sediment accumulation affect macroinvertebrate assemblages by altering substrate composition and changing the suitability of the substrate for some taxa (Hynes, 1970; Waters, 1995). Waters (1995) found that suspended sediments can impact stream fauna directly by interference with filterfeeding mechanisms or reducing visual feeding efficiency and indirectly by reducing light levels to the point of triggering drift behaviour. Streams exposed to continuous sediment accumulation may consist less benthic macroinvertebrate diversity and numerically dominated by fine sediment tolerant taxa.

Biological methods have been developed largely to measure the health of, and stresses on an aquatic ecosystem (Birk et al., 2012). Unlike chemical monitoring, the advantage of biomonitoring of aquatic ecosystems lies in the ability of biological communities to reflect not only the quality of the water, but also the overall ecological status of the ecosystem (Rosenberg and Resh, 1993). However limited information is available on Ethiopian stream faunal diversity in general and their use for stressor analysis in particular. Some studies conducted in streams and wetlands of Ethiopia showed benthic macroinvertebrate are effective for evaluating the ecological 
status of aquatic system (Aschalew, 2012; Mereta et al., 2013; Aschalew, 2014). Therefore this study was conducted to analyse the relationship between benthic macroinvertebrate assemblage- response and various stressor types in central highland streams of Ethiopia.

\section{Materials and methods}

\section{Study Area}

This study was conducted in upper Awash basin, lying between latitude $9^{\circ} 00^{\prime} \mathrm{N}$ and $9^{\circ} 10^{\prime} \mathrm{N}$ and longitudes $38^{\circ} 00^{\prime} \mathrm{E}$ and $38^{\circ} 40^{\prime} \mathrm{E}$ (Figure 1). The altitude ranged between 2100 to $2400 \mathrm{~m}$ a.s.l. The rainfall distribution is bimodal: a short rainy season from March to April and the main rains from June to September with mean annual rainfall above $1000 \mathrm{~mm}$. The discharge fluctuates concurrently with the rainfall intensity. For example average discharge measured at Ginchi town from 2001 to 2009 indicate that maximum discharges from July to September with the highest peak in August $\left(16.7 \mathrm{~m}^{3} / \mathrm{s}\right)$ and the minimum in November, December, January and May with the lowest in December $\left(0.16 \mathrm{~m}^{3} / \mathrm{s}\right)$.

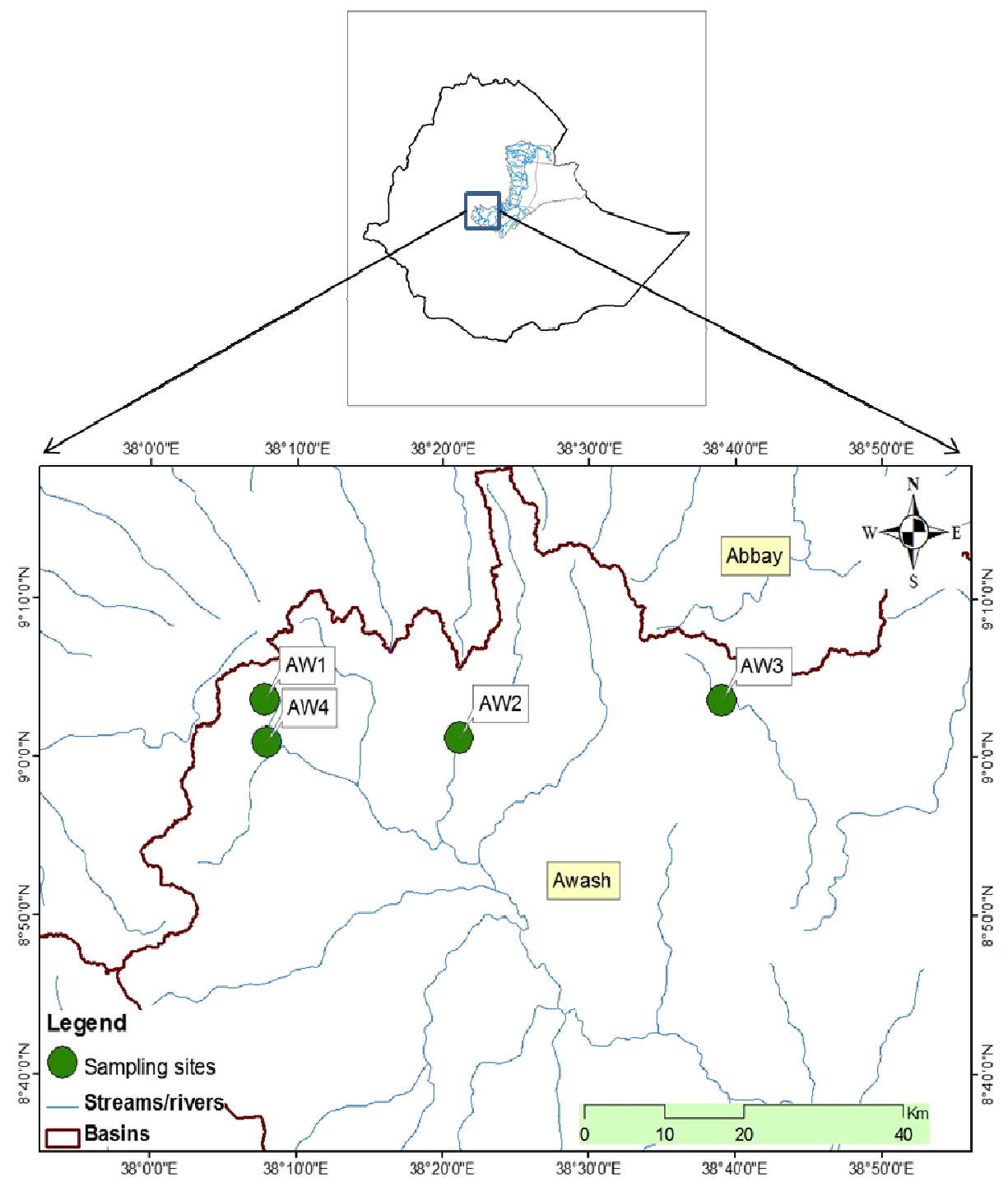

Figure 1: Map showing study sites in Awash basin 
Four investigation sites were selected to include three major stressor types in the central highland streams. A reference site coded as AW1 is located inside state protected natural forest (Chilimo forest) about $6 \mathrm{~km}$ from Ginchi town. The forest is part of the dry Afro-montane forest dominated by mixed broad leaved and coniferous trees such as Juniperus procera, Podocarpus falcatus, Prunus africanum, Olea europaea, and Hagenia abyssinica. A site coded as AW4 was established about 1 $\mathrm{km}$ below a paper mill effluent discharge near Ginchi town. This site may represent most streams used as receivers of untreated waste from both domestic and industrial sources in Awash basin. The other important stressor in the study area is agricultural activities and this is represented by Berga stream (coded as AW2). The catchment of Berga stream is entirely used for mixed agricultural activities (about 85\% crop farming and animal production). The runoff from agricultural farm lands is rich in nitrates and phosphates that lead to eutrophication. Siltation caused by erosion from the unprotected watershed is another stressor in the region. In rural areas the erosion source is typically soil degradation due to intensive and inadequate agricultural practices whereas in urban areas the source is typically construction activities and fine particulate organic matter from domestic damping. A site coded as AW3 is located about $1 \mathrm{~km}$ downstream from water treatment plant that carries fine sediment and cause remarkable siltation in the stream bed.

\section{Habitat description}

Sampling sites vary in organic habitat composition: the reference site was dominated by leave fall from big trees and stream bank shrubs; AW4 was covered by decomposable fine organic matter at a considerable depth; AW2 was dominated by filamentous algae especially during low flow months (January and May) and AW3 was characterized by absence of organic habitat. At all sampling sites, $80 \mathrm{~m}$ stretch length with representative habitat types was considered.

\section{Sampling}

Water quality parameters and benthic macroinvertebrate sampling was conducted monthly from November 2011 - June, 2012. Samples were not collected in July, August and September due to heavy rain combined with high water level, and in October to give regeneration time for benthic community. Environmental and benthic macroinvertebrate data were collected from all sites on one day in the last week of the months. To reduce diurnal variability in physicochemical variables, all water samples and measurements were taken between 9:30a.m. and 1:00p.m. To minimize the impact of physical disturbance during sampling, the $80 \mathrm{~m}$ sampling reach was divided into two $40 \mathrm{~m}$ stretches and sampling was performed alternately from the two stretches (eg. stretch 1 in November, stretch 2 in December etc.).

\section{Physicochemical parameter}

Physical and chemical variables were measured to find out potential relationships between variables and benthic macroinvertebrate data. Substrate composition was visually estimated in accordance with particle size: psammal $(<0$, $2 \mathrm{~cm})$, akal $(0,2-2 \mathrm{~cm})$, microlithal (2-6 $\mathrm{cm})$, mesolithal $(6-20 \mathrm{~cm})$, macrolithal (20$40 \mathrm{~cm})$, megalithal $(>40 \mathrm{~cm}$ and bed rock). Flow velocity and water depth were measured using velocity meter. Water quality parameters including temperature, $\mathrm{pH}$, dissolved oxygen and conductivity were measured using a portable WTW multi-parameter probe on site. Two liters of 
water were collected and stored in ice box until return to the Laboratory of JIJE labo PLC and National Fishery and Aquatic Life Research center. Total phosphorus (TP) and five day biochemical oxygen demand $\left(\mathrm{BOD}_{5}\right)$ were analyzed following standard methods APHA (1997).

\section{Macroinvertebrate sampling}

Benthic macroinvertebrates were collected using standard hand net with frame width of $25 * 25 \mathrm{~cm}$ and mesh size $500 \mu \mathrm{m}$. A method suitable to sample variety of habitat types, multi-habitat sampling (MHS) scheme, was implemented to sample major habitats in proportional representation within 40m sampling reach following Moog (2005). A sample consists of 20 sampling units was taken from all habitat types each with a share of at least 5 $\%$ habitat coverage. A sampling unit is a sample performed by positioning the net and disturbing the substrate in a quadratic area that equals the frame area of the net. The sample materials collected from all sampling units were mixed to form one homogenous sample and preserved in $4 \%$ formaldehyde (final concentration).

In laboratory, a complete sample was passed through a set of sieves $(5000,3000$, 2000, 1000 and 500 $\mu \mathrm{m}$ mesh size) in order to wash formalin and separate size class of macroinvertebrate groups under tap water. Macroinvertebrate trapped in the coarse fraction of the sieve were sorted completely by naked eyes. Organisms trapped in the smaller fraction of the sieve were sorted with help of light microscope. In case of high abundance of a taxon sub sampling was applied according to Barbour et al. (1999). Identification has been done based on the available literature (Merritt and Cummins, 1996; de Moor et al., 2003) and help of taxonomic specialists.

\section{Data analysis}

Mean values of physicochemical parameters were calculated and compared among four sites. One way ANOVA with Bonferroni post hoc test was used for significant test between stressor types both for environmental variables and benthic invertebrate metrics. Non-metric Multidimensional Scaling (NMS) was used to show variation among sampling sites based on the composition of the benthic macroinvertebrate community. When ordination axes are plotted in scatter diagrams, the relative positions of the sampling sites reflect their underlying similarities or differences i.e. sites appear close to each other in the scatter diagram are more similar taxa composition than those sites that are far apart. Data sets were tested for normality, and where necessary, $\log (\mathrm{x}+1)$ transformation were performed to minimize the influence of non-normality on statistical results.

\section{Results and Discussion Environmental variables}

Environmental variables measured during the sampling period were summarized in table 1. Water quality parameters such as oxygen concentration, conductivity and total phosphorus showed significant difference among stressor types $(\mathrm{p}<0.05)$. In tropical streams temporal variability may not be significantly influenced by temperature changes, but instead could be influenced by changes in water availability or precipitation patterns (Buss et al., 2004). For example, conductivity decreased during light rainy season in AW4 which may be due to dilution effects and reduced resident time of the polluted water from paper mill waste. Conversely conductivity increased slightly in the reference site and this may be due to the transport of particulate matters into the 
streams by mild flood. The dissolved oxygen (DO) pattern was also somewhat irregular in each stressor types with the highest value in agricultural streams and the lowest in paper mill waste site. This indicates that the natural mechanisms of oxygen addition (photosynthesis) and oxygen consumption (decomposition and respiration) processes were affected by specific stressors. The highest concentration of oxygen in agricultural sites may be due to the dominance of photosynthetic algae favoured by nutrient inputs whereas severe oxygen depletion in paper waste site was due to high decomposition process. Oxygen concentration is identified as one of the most important predictors of benthic invertebrate assemblages, where low oxygen concentration leads to a reduction of taxa richness, loss of sensitive taxa and increase of tolerant taxa (Sundermann et al., 2013).

Table 1: Environmental variables measured during sampling period from four sampling sites.

Letter a, b, c and d represents stressor types: reference, agriculture, siltation and paper mill waste respectively and indicate significant mean difference following Boniferri post hoc tests. $\mathrm{p}<0.05$.

\begin{tabular}{|c|c|c|c|c|}
\hline & \multicolumn{4}{|l|}{ Stressor type } \\
\hline & $\begin{array}{l}\text { Reference } \\
n=8\end{array}$ & $\begin{array}{l}\text { Agriculture } \\
n=8\end{array}$ & $\begin{array}{l}\text { Siltation } \\
\mathrm{n}=7\end{array}$ & $\begin{array}{l}\text { Paper mill waste } \\
\mathrm{n}=8\end{array}$ \\
\hline Altitude (m a.s.l.) & 2358 & 2127 & 2362 & 2197 \\
\hline$\%$ Riffle & 78 & 75 & 71 & 97 \\
\hline$\%$ pool & 22 & 25 & 29 & 5 \\
\hline Mean depth $(\mathrm{cm})$ & $14.3 \pm 1.5$ & $16.4 \pm 5.4$ & $14.3 \pm 4$ & $15.4 \pm 5$ \\
\hline Mean velocity $(\mathrm{m} / \mathrm{s})$ & $0.34 \pm 0.28^{\text {bd }}$ & $0.58 \pm 0.4^{\mathrm{ac}}$ & $0.34 \pm 0.3^{\mathrm{bd}}$ & $0.68 \pm 0.4^{\mathrm{ac}}$ \\
\hline Mean discharge $\left(\mathrm{m}^{3} / \mathrm{s}\right)$ & $0.1 \pm 0.1^{\text {bd }}$ & $0.5 \pm 0.2^{\mathrm{ac}}$ & $0.1 \pm 0.1^{\mathrm{bd}}$ & $0.3 \pm 0.3^{\mathrm{ac}}$ \\
\hline $\mathrm{pH}$ & $8.2 \pm 0.4^{\mathrm{d}}$ & $8.6 \pm 0.1^{\mathrm{d}}$ & $8.2 \pm 0.4^{\mathrm{d}}$ & $7.6 \pm 0.4^{\mathrm{abc}}$ \\
\hline Conductivity $(\mu \mathrm{S} / \mathrm{cm})$ & $252.2 \pm 35.1^{\mathrm{bcd}}$ & $306.8 \pm 29^{\text {acd }}$ & $156.1 \pm 61.5^{\mathrm{abd}}$ & $429.6 \pm 46.7^{\mathrm{abc}}$ \\
\hline Dissolved oxygen $(\mathrm{mg} / \mathrm{l})$ & $7.8 \pm 1^{\mathrm{d}}$ & $8.9 \pm 1.6^{\mathrm{cd}}$ & $5.8 \pm 1.2^{\mathrm{bd}}$ & $3.1 \pm 2^{\mathrm{abc}}$ \\
\hline Dissolved oxygen $(\%)$ & $102.9 \pm 12.4^{\mathrm{d}}$ & $130.1 \pm 23^{\mathrm{cd}}$ & $93.0 \pm 21.9^{\text {bd }}$ & $47.7 \pm 31.6^{\mathrm{abc}}$ \\
\hline Temperature $\left({ }^{\circ} \mathrm{C}\right)$ & $18.2 \pm 2.5^{\mathrm{cd}}$ & $20.0 \pm 3.1^{\mathrm{a}}$ & $23.3 \pm 2.3^{\mathrm{a}}$ & $22.9 \pm 1.1^{\mathrm{a}}$ \\
\hline $\mathrm{BOD}_{5}(\mathrm{mg} / \mathrm{l})$ & $3.9 \pm 1.4^{\mathrm{d}}$ & $6.8 \pm 2.4^{\mathrm{d}}$ & $4.3 \pm 0.9^{\mathrm{d}}$ & $98.3 \pm 69.2^{\mathrm{abc}}$ \\
\hline Total phosphorus (mg/l) & $0.08 \pm 0.04^{\mathrm{d}}$ & $0.2 \pm 0.1^{\mathrm{d}}$ & $0.05 \pm 0.2^{\mathrm{d}}$ & $2.1 \pm 1^{\mathrm{abc}}$ \\
\hline
\end{tabular}

Letter $\mathrm{a}, \mathrm{b}, \mathrm{c}$ and $\mathrm{d}$ represents stressor types: reference, agriculture, siltation and paper mill waste respectively and indicate significant mean difference following Boniferri post hoc tests. $p<0.05$.

\section{Macroinvertebrate Communities}

Macroinvertebrate taxa collected during sampling period were listed in Table 2. The result showed that macroinvertebrate community structure varied among stressor types. For example, in a paper mill impacted site, Oligochaeta and red Chironomidae were the dominant invertebrates throughout the sampling period. This finding agrees with the accepted view that tolerant species become abundant in degraded streams and rivers (Barbour et al., 1996; Karr and Chu, 1999). Moderately tolerant species such as Baetidae, Caenidae, Hydropsychidae and Planariidae were numerically dominant in agriculture and siltation sites. This can be explained by the availability of nutrient from the catchment at a level to enhance somewhat sensitive taxa diversity. Sensitive taxa such as Perlidae, Scirtidae, Heptagnidae and Lepidostomatidae were 
common in reference sites and the lack of the degradation of the streams. these taxa in stressed sites clearly indicates

Table 2: Benthic macroinvertebrate diversity and relative abundance along stressor types. RF-

Reference, PM- Paper mill waste, AG- Agriculture, SI- Siltation due to reservoir flushing. symbols indicate abundance of taxa: R- rare/single (1-5), F- few (6-10), C-common (10-50), A - Abundant (51-100), M- mass (>100).

\begin{tabular}{|c|c|c|c|c|c|c|c|c|c|}
\hline Taxa & $\mathrm{RF}$ & $\overline{\mathrm{PM}}$ & $\mathrm{AG}$ & SI & Taxa & $\mathrm{RF}$ & PW & $\mathrm{AG}$ & SI \\
\hline Planariidae & $\mathrm{C}$ & & $\mathrm{C}$ & $\mathrm{C}$ & Elmidae & & & & \\
\hline Corbiculidae & $\mathrm{R}$ & & $\mathrm{R}$ & & Stenelmis & $\mathrm{F}$ & & $\mathrm{R}$ & \\
\hline Physidae & & $\mathrm{F}$ & $\mathrm{R}$ & & Potamocares & $\mathrm{R}$ & & $\mathrm{R}$ & \\
\hline Lymnaeidae & $\mathrm{R}$ & & & & Microdinodes & $\mathrm{R}$ & & $\mathrm{R}$ & $\mathrm{R}$ \\
\hline Planorbidae & $\mathrm{R}$ & & $\mathrm{C}$ & & Elmidae larva & $\mathrm{C}$ & & $\mathrm{R}$ & \\
\hline Oligichaeta & $\mathrm{R}$ & M & $\mathrm{C}$ & $\mathrm{C}$ & Hydrophilidae & & & $\mathrm{R}$ & $\mathrm{C}$ \\
\hline Perlidae & & & & & Leptelmis & & & $\mathrm{R}$ & \\
\hline Neoperla sp. & $\mathrm{C}$ & & & & Dytiscidae & & & & \\
\hline Baetidae & & & & & Agabus & $\mathrm{R}$ & & & \\
\hline Acanthiops sp. & $\mathrm{C}$ & & & & & & & & \\
\hline Baetis & M & & M & M & Laccobius & & & & $\mathrm{R}$ \\
\hline Cloeon & M & & M & $\mathrm{C}$ & Rhantus & $\mathrm{F}$ & & $\mathrm{C}$ & $\mathrm{R}$ \\
\hline Baetidae sp.2 & A & & & & Hygrotus & $\mathrm{R}$ & & & $\mathrm{C}$ \\
\hline Caenidae & & & & & Hydroglyphus & $\mathrm{R}$ & & & $\mathrm{F}$ \\
\hline Afrocaenis & M & & M & A & & & & & \\
\hline Heptageniidae & $\mathrm{C}$ & & M & & Hydaticus & & & $\mathrm{R}$ & \\
\hline Afronurus & $\mathrm{C}$ & & M & & Potamonectes & $\mathrm{R}$ & & & \\
\hline Tricorythidae & & & & & Hyphydrus & & & & $\mathrm{F}$ \\
\hline Tricorythodes sp. & $\mathrm{F}$ & & M & & & & & & \\
\hline Aeshnidae & $\mathrm{C}$ & & $\mathrm{R}$ & & Hydrophilidae & & & & \\
\hline Libellulidae & $\mathrm{R}$ & & $\mathrm{C}$ & $\mathrm{R}$ & Paracymus & & & & $\mathrm{R}$ \\
\hline Coenagrionidae & $\mathrm{R}$ & & $\mathrm{F}$ & $\mathrm{R}$ & Cercyon & & & & $\mathrm{R}$ \\
\hline Gomphidae & $\mathrm{R}$ & & $\mathrm{F}$ & & Gyrinidae L. & $\mathrm{R}$ & & $\mathrm{C}$ & $\mathrm{C}$ \\
\hline Corixidae & & & & & Dineutus & $\mathrm{C}$ & & & \\
\hline Corixidae sp.2 & $\mathrm{R}$ & & & $\mathrm{F}$ & Gyrinus & & & & $\mathrm{F}$ \\
\hline Naucoridae & $\mathrm{C}$ & & A & $\mathrm{R}$ & Aulonogyrus & $\mathrm{F}$ & & $\mathrm{C}$ & $\mathrm{R}$ \\
\hline Naucoris & $\mathrm{R}$ & & $\mathrm{C}$ & & Laccophilus & & & & \\
\hline Nepidae & & & & & Psephenidae & & & & \\
\hline Laccotrephes & $\mathrm{C}$ & & & $\mathrm{F}$ & Eubrianax & & & $\mathrm{F}$ & \\
\hline Notonetidae & & & $\mathrm{R}$ & & Scirtidae & $\mathrm{F}$ & & & \\
\hline Enithares & $\mathrm{R}$ & & & $\mathrm{R}$ & Chironomidae & & & & \\
\hline Gerridae & & & & & Chironominae & $\mathrm{F}$ & M & A & $\mathrm{C}$ \\
\hline Gerris & $\mathrm{F}$ & & $\mathrm{F}$ & & Tanypodinae & M & A & M & $\mathrm{R}$ \\
\hline Micronectidae & & & & & Orthocladiinae & $\mathrm{C}$ & $\mathrm{F}$ & $\mathrm{C}$ & \\
\hline Micronecta & $\mathrm{R}$ & & $\mathrm{R}$ & $\mathrm{R}$ & Tanytarsini & $\mathrm{C}$ & & & \\
\hline Veliidae & & & & & Ceratopogonidae & $\mathrm{R}$ & & $\mathrm{R}$ & \\
\hline Rhagovelia & $\mathrm{R}$ & & $\mathrm{R}$ & & Simulidae & M & $\mathrm{C}$ & A & A \\
\hline Hydropsychidae & & & & & Tipulidae & $\mathrm{C}$ & & $\mathrm{F}$ & $\mathrm{R}$ \\
\hline Cheumatopsyche & $\mathrm{F}$ & & $\mathrm{C}$ & $\mathrm{R}$ & Musidae & $\mathrm{F}$ & & $\mathrm{R}$ & \\
\hline Hydatomanicus & $\mathrm{R}$ & & & $\mathrm{F}$ & Culicidae & $\mathrm{R}$ & & $\mathrm{C}$ & $\mathrm{R}$ \\
\hline Hydropsyche & A & & M & & Tabanidae & $\mathrm{F}$ & & $\mathrm{F}$ & $\mathrm{R}$ \\
\hline Leptoceridae & $\mathrm{R}$ & & & & Psychodidae & & $\mathrm{C}$ & & \\
\hline Lepidostomatidae & $\mathrm{C}$ & & & & Ephydridae & $\mathrm{R}$ & $\mathrm{C}$ & & $\mathrm{R}$ \\
\hline
\end{tabular}




\section{Benthic Macroinvertebrate Metrics and Stressor Types}

Five metrics representing richness, composition and tolerance were selected as core metrics and showed statistically significant difference among stressor types (Table 3). The first sign of impairment are often associated with changes in the relative proportions of various taxa.

Table 3: The average value (Mean $\pm \mathrm{SE}$ ) of core macroinvertebrate metrics selected to determine variability among stressor types. Letter $\mathrm{a}, \mathrm{b}, \mathrm{c}$ and $\mathrm{d}$ represents stressor type: reference, agriculture, siltation and paper mill waste respectively and indicate significant mean difference following Boniferri post hoc tests. $\mathrm{p}<0.05$

\begin{tabular}{lllll}
\hline & \multicolumn{3}{l}{ Stressor type } & \\
\cline { 2 - 5 } & $\begin{array}{l}\text { Reference } \\
\mathrm{n}=8\end{array}$ & $\begin{array}{l}\text { Agriculture } \\
\mathrm{n}=8\end{array}$ & $\begin{array}{l}\text { Siltation } \\
\mathrm{n}=7\end{array}$ & $\begin{array}{l}\text { Paper mill waste } \\
\mathrm{n}=8\end{array}$ \\
\hline Taxa richness & $30.0 \pm 4.4^{\mathrm{bcd}}$ & $25.0 \pm 6.4^{\mathrm{acd}}$ & $15.0 \pm 3.7^{\mathrm{abd}}$ & $2.5 \pm 1.6^{\mathrm{abc}}$ \\
EPT richness & $10.0 \pm 2.0^{\mathrm{bcd}}$ & $7.0 \pm 1.7^{\mathrm{acd}}$ & $3.1 \pm 0.7^{\mathrm{abd}}$ & $0^{\mathrm{abc}}$ \\
Margalef's index & $2.8 \pm 0.5^{\mathrm{bcd}}$ & $2.3 \pm 0.2^{\mathrm{acd}}$ & $1.9 \pm 0.3^{\mathrm{abd}}$ & $0.1 \pm 0.1^{\mathrm{abc}}$ \\
$\%$ EPT - BHC & $12 \pm 3^{\mathrm{bcd}}$ & $7.2 \pm 3^{\mathrm{acd}}$ & $0^{\mathrm{ab}}$ & $00^{\mathrm{ab}}$ \\
ASPT & $6.1 \pm 0.6^{\mathrm{bcd}}$ & $5.5 \pm 0.5^{\mathrm{acd}}$ & $4.2 \pm 0.3^{\mathrm{abd}}$ & $2.3 \pm 0.6^{\mathrm{abc}}$ \\
\hline
\end{tabular}

Taxa richness is the simplest diversity measures used for evaluating different stressors (Royer et al., 2001; Ofenboeck et al., 2004). A decrease of taxa richness in response to disturbance is reported by many authors (Barbour et al., 1996; Karr and Chu, 1999) but others like Metcalfe (1989) indicated increase of taxa richness with intermediate disturbance. In this study significant number of taxa reduction was observed in paper mill waste site while agricultural impacted site showed elevated taxa richness which could be due to availability of nutrient for moderately sensitive invertebrates. EPT taxa are widely used metric in many biominitoring approaches as the components are well known for their sensitivity to anthropogenic impacts (Rosenberg and Resh, 1993). EPT taxa groups were completely absent in paper mill waste site throughout the sampling months, which confirms the sensitivity of these groups to heavily polluted sites. EPT -BHC (EPT without Baetidae, Hydropschidae and Caenidae) discriminated reference, agriculture and siltation sites successfully. In siltation site,
EPT richness was represented by Baetidae, Caenidae and Hydropschidae throughout the sampling period and thus exclusion of these taxa improved the performance of EPT metrics in siltation sites. Biotic scores are widely used in water quality assessments because of their advantage in providing information on specific taxon response to disturbance other than diversity. This could be the reason that ASPT- ETHbios (Aschalew, 2014) revealed high discrimination efficiency between stressor types.

\section{Relation between Core Metrics and Environmental Variables}

Correlation analysis between macroinvertebrate metrics and the environmental variables indicated significant correlation $(\mathrm{p}<0.05)$. Environmental variables that showed strong correlation with BMI metric were dissolved oxygen, $\mathrm{BOD}_{5}$ and total phosphorus. These parameters are reported as good indicators of organic pollution (Owens, 1991; Biermann, 1996; Barbour et al. 1999; Moog, 2005). The impairment at AW4 is extremely high as it was expected because 
of continuous untreated waste discharge from the paper mill in the study area. Currently, most paper mills use at least a secondary treatment process which involves reacting the effluent with oxygen and microorganisms to remove oxygen- consuming materials (Biermann, 1996). The absence and /or non-functioning of such treatment plant or poor implementation of environmental laws in the region was clearly reflected by abiotic and biotic variables.

Table 4: Pearson's correlation coefficients between selected environmental parameters and values of benthic macroinvertebrate metrics

\begin{tabular}{|c|c|c|c|c|c|c|c|c|c|}
\hline \multicolumn{10}{|c|}{ Pearson Correlation } \\
\hline & $\begin{array}{l}\text { Cond } \\
(\mu \mathrm{S} / \mathrm{cm})\end{array}$ & $\begin{array}{l}\mathrm{DO} \\
(\mathrm{mg} / \mathrm{l})\end{array}$ & $\begin{array}{l}\mathrm{DO} \\
(\%)\end{array}$ & $\mathrm{H}_{2} \mathrm{O}\left({ }^{\circ} \mathrm{C}\right)$ & $\begin{array}{l}\mathrm{BOD}_{5} \\
(\mathrm{mg} / \mathrm{l})\end{array}$ & $\mathrm{TP}(\mathrm{mg} / \mathrm{l})$ & $\operatorname{Depth}(\mathrm{m})$ & $\operatorname{Veloc}(\mathrm{m} / \mathrm{s})$ & $\begin{array}{l}\mathrm{Q} \\
(\mathrm{m} 3 / \mathrm{s})\end{array}$ \\
\hline Taxa richness &,$- 461 * *$ & ,728** & ,647** &,$- 678 * *$ &,$- 664 * *$ &,$- 721 * *$ &,- 111 &,$- 439 *$ &,- 106 \\
\hline EPT richness &,$- 467 * *$ &, $666 * *$ &, $571 * *$ &,$- 752 * *$ &,$- 614 * *$ &,$- 683 * *$ &,- 164 &,$- 513 * *$ &,- 215 \\
\hline$\%$ ЕРТ -BHC &,- 180 &, $599 * *$ &, $488 * *$ &,$- 772 * *$ &,$- 415^{*}$ &,$- 460 * *$ & ,022 &,$- 368 *$ &,- 111 \\
\hline Margalef indeex &,$- 619 * *$ &, $755^{* *}$ &, $699 * *$ &,$- 551 * *$ &,$- 735^{* *}$ &,$- 802 * *$ &,- 181 &,$- 490 * *$ &,- 165 \\
\hline ASPT &,$- 528 * *$ &, $809 * *$ &, $728 * *$ &,$- 701 * *$ &,$- 742 * *$ &,$- 779 * *$ &,- 052 &,$- 472 * *$ &,- 063 \\
\hline
\end{tabular}

* Correlation is significant at the 0.05 level (2-tailed), ** Correlation is significant at the 0.01 level (2-tailed).

In the NMS scatter plot, three major distinct cluster groups were observed irrespective of sampling months. Based on stressor related classification, study sites can be grouped as good sites (reference and agriculture), moderate sites (siltation), and bad sites (paper mill waste). From the point of river quality assessment concepts, this benthic macroinvertebrate grouping could basically be divided into communities of very good, good, moderate and bad status. Siltation may not affect the water quality at a level to exclude BMI but the loss of micro habitat lead to significant reduction of moderately sensitive taxa groups in abundance. NMS scatter plot showed a clear discrimination of reference and agricultural because of the dissimilarity of sensitive taxa. 


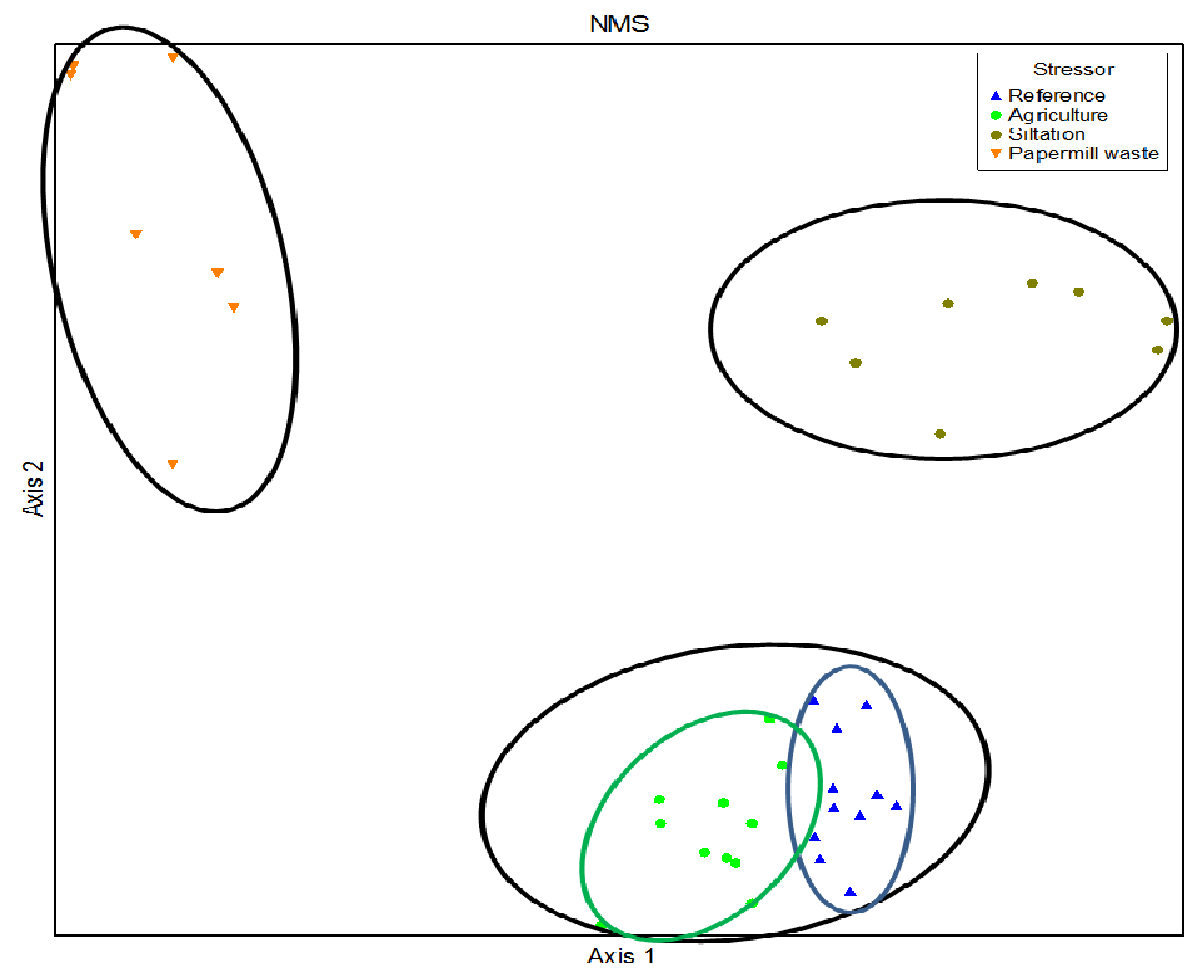

Figure 2: Non-metric multidimentional scaling scatter plot for sixty six taxa collected during the sampling period. Stress value is 4.6.

\section{Conclusion}

The investigated sites represent major stressor groups in highland streams and rivers of Ethiopia. There were no significant disturbances by human occurred at the reference site during the sampling period. Thus the changes in benthic macroinvertebrate communities clearly reflect the impact of the stressor either on water quality or habitat degradation. A trend in the benthic community was observed to predict alterations caused by different stressors, mainly the point source pollution, as the case in paper mill waste. The correlation analysis demonstrated strong relationship between sensitive benthic invertebrate indices (e.g. taxa richness, EPT taxa, ASPT) and environmental variables that indicated ecological disturbances (e.g. conductivity, dissolved oxygen, total phosphorus).
Owing the results of the present study, selected benthic macroinvertebrate indices provide ecologically sound information for management purpose in the river catchment, to implement environmental laws and evaluate the improvement afterwards.

\section{Acknowledgment}

The author would like to thank Austrian Development Cooperation through APPEAR-program for financing this project. The author also thanks National Fishery and Aquatic Life Research Center for arranging field and laboratory facilities and for covering related costs. I am also grateful to all NFALRC staffs especially Mr. Yard Tigabu, Dr. Adamineh Dagne, Mr. Sitanu Abere and Mr. Alemayehu Wubie for their immense help in facilitation, field and laboratory work. 


\section{Reference}

APHA (1997). Standard methods for the examination of water and wastewater (20th ed.).Washington: APHA (American Public Health Association).

Armitage, P.D., Moss, D., Wright, J.F. and Furse, M.T. (1983). The performance of a new biological water quality score system based on macroinvertebrates over a wide range of unpolluted running-water sites. Water Research, 17: 333-347.

Aschalew, L. (2014). Development of biological monitoring systems using benthic invertebrates to assess the ecological status of central and southeast highland rivers of Ethiopia. $\mathrm{PhD}$ Thesis, University of Natural Resources and Life Sciences at Vienna, Austria: 163 pp.

Aschalew, L. (2012). Testing bioassessment methods in some highlands of Ethiopia. LAP-LAMBERT Academic publishing, ISBN 978-3-659-15484-3.

Barbour, M.T., Gerritsen, J., Snyder, B.D. and Stribling, J.B. (1999). Rapid Bioassessment Protocols for Use in Streams and Wadeable Rivers: Periphyton, Benthic Macroinvertebrates and Fish, 2nd edn. EPA 841-B-99-002. U.S. Environmental Protection Agency, Office of Water, Washington, DC.

Barbour, M. T., Gerritsen, J., Griffith, G. E., Frydenbourg, R., McCarron, E., White, J. S. and Bastian, M. L. (1996). A framework for biological criteria for Florida streams using benthic macroinvertbrates. Journal of the North American Benthological Society, 15: 185-211.

Biermann, C.J. (1996). Pulping and paper making. Academic Press, San Diego, California.

Birk, S., Bonne, W., Borja, A., Brucet, S., Courrat, A., Poikane, S., Solimini, A., van de Bund, W., Zampoukas, N. and Hering, D. (2012). Three hundred ways to assess Europe's surface waters: An almost complete overview of biological methods to implement the Water Framework Directive. Ecological Indicators 18, 31-41.

Buss D.F. and Salles, F.F. (2004). Using Baetidae species as biological indicators of environmental degradation in a Brazilian river basin. Environ Monit Assess., 130: 365-372.

Cooper, J.R., Gilliam, J.W. and Jacobs, T.C. (1986). Riparian areas as a control of nonpoint pollutants. In, D.L. Correll (ed.) Watershed Research Perspectives. Smithsonian Institution Press, Washington D.C. pp. 166-190.

De Moor I.J, Day, J.A. and de Moor, F.C. (2003). Guides to the Freshwater invertebrates of South Africa. Water Research Commission project no. 916, ISBN 1-77005-055-8.

Giller, P.S. and Twomey, H. (1993). Benthic macroinvertebrate community organisms in two contrasting riversbetween-site differences and seasonal patterns. Biology and environment: Proceedings of the Royal Irish Academy, 93B: 114-126.

Hall, M.J., Closs, G.P. and Riley, R.H. (2001). Relationships between land use and stream invertebrate community structure in a South Island, New Zealand, coastal stream. New Zealand Journal of Marine and Freshwater Research, 35: 591-603.

Hellawell, J.M. (1986). Biological Indicators of Freshwater Pollution and Environmental Management. Elsevier, London: 546 pp.

Hynes, H.B.N. (1970). The ecology of running waters. Liverpool University Press, Liverpool. pp. 555.

Karr, J.R. and Chu, E.W. (1999). Restoring life in running waters: Better biological monitoring. Island Press, Washington, D.C. 
Lowrance, R., Todd, R., Fail, J., Hendrickson, O., Leonard, R. and Asmussen, L. (1984). Riparian forests as nutrient filters in agricultural watersheds. Bioscience 34(6), 374-377.

McLeay, D.J. (1987). Aquatic toxicity of pulp and paper mill effluent: a review. Environmental Protection Series Report No. EPS 4/PF/1. Conservation and Protection, Environment Canada, Ottawa, Ont. 191 pp.

Mereta, S., Boetsa, P., De Meesterc, L. and Goethalsa, P.L.M. (2013). Development of a multimetric index based on benthic macroinvertebrates for the assessment of natural wetlands in Southwest Ethiopia. Ecological Indicators, 29: 510-521.

Merritt, R.W. and Cummins, K.W. (1996). An introduction to the aquatic insects of North America. 3rd edition. Kendal Hund Publishing, Dubuque, Iowa.

Metcalfe, J.L. (1989). Biological water quality assessment of running waters based on macroinvertebrate communities: history and present status in Europe. Environ. Pollut. 101 - 139.

Moog, O. (2007). Manual on Pro-Rata MultiHabitat-Sampling of Benthic Invertebrates from Wadeable Rivers in the HKH-Region. Deliverable 8, Part 1 for ASSESS-HKH, European Commission, 29 pp. Available from: http://www.assess-hkh.at.

Negishi, J.N., Inoue, M. and Nunokawa, M. (2002). Effects of channelisation on stream habitat in relation to a spate and flow refugia for macroinvertebrates in northern Japan. Freshwater Biol. 47: 1515-1529.

Ofenboeck, T., Moog, O. Gerritsen, J. and Barbour, M. (2004). A stressor specific multimetric approach for monitoring running waters in Austria using benthic macro-invertebrates. Hydrobiologia, 516: 251-268.

Owens, J.W. (1991). The hazard assessment of pulp and paper effluents in the aquatic environment: A review. Environ. Toxicol. Chem., 10: 15111540.

Reed, J.L., Campbell, I.C. and Bailey, P.C.E. (1994). The relationship between invertebrate assemblages and available food at forest and pasture sites in three south-eastern Australian streams. Freshwater Biology, 32: 641- 650.

Rosenberg, D.M. and Resh, V.H. (1993). Introduction to freshwater biomonitoring and benthic macroinvertebrates. In: Rosenberg, D.M.; Resh, V.H. ed. Freshwater biomonitoring and benthic macroinvertebrates, New York, London, Chapman and Hall. pp. 1-9.

Royer, T.V., Robinson, C.T. and Minshall, G.W. (2001). Development of macroinvertebrate-based index for bioassessment of Idaho rivers. Environ.

Manage., 27: 627-636

wadeable rivers in the $\mathrm{HKH}$ region. Deliverable No. 8 - $\underline{w w w . a s s e s s-}$ HKH.at

Sundermann, A., Gerhardt, M., Kappes, H. and Haase, P. (2013). Stressor prioritisation in riverine ecosystems: Which environmental factors shape benthic invertebrate assemblage metrics? Ecological Indicators, 27: 8396.

Walsh, C.J., Sharpe, A. Breen, P.F. and Sonneman J.A. (2001). Effects of urbanization on streams of the Melbourne region, Victoria, Australia. Freshwater Biology, 46: 535-551.

Waters, T.F. (1995). Sediment in streams: sources, biological effects and control. American Fisheries Society, Bethesda, Maryland. $251 \mathrm{pp}$. 